\title{
Perbedaan Efektivitas Diskusi Kelompok dan Penyuluhan Pendidikan Seksual terhadap Perubahan Persepsi tentang Perilaku Seksual Siswi SMAN 1 Kandat Kabupaten Kediri
}

\author{
Mayasari Putri Ardela ${ }^{1}$, Nirmala Gina Prabawati ${ }^{2}$, Linda Ratna Wati ${ }^{3}$ \\ ${ }^{1}$ Program Studi Kebidanan (D-IV), Fakultas Ilmu Kesehatan, Universitas Kadiri \\ ${ }^{2}$ Bagian Kebidanan dan Kandungan Rumah Sakit Universitas Brawijaya, Malang \\ ${ }^{3}$ Program Studi S1 Kebidanan, Fakultas Kedokteran, Universitas Brawijaya \\ Corresponding author: Mayasari Putri Ardela (mayasari.ardela@unik-kediri.ac.id) \\ Received: December, 16 2019; Accepted: January, 19 2020; Published: March, 162020
}

\begin{abstract}
ABSTRAK
Pesatnya pertumbuhan dan perkembangan pada remaja ditunjukkan dengan meningkatnya minat terhadap seks. Hal ini terlihat dari perilaku pacaran remaja yang semakin mengarah pada perilaku seksual yang berisiko. Remaja perlu mendapatkan informasi yang benar mengenai proses reproduksi. Penelitian ini bertujuan mengidentifikasi dan menganalisis perbedaan efektivitas diskusi kelompok dan penyuluhan pendidikan seksual terhadap perubahan persepsi tentang perilaku seksual siswi. Studi eksperimental menggunakan prepost test with control group design yang dilakukan terhadap siswi kelas XII IPA. Sampel dipilih menggunakan purposive sampling, sehingga didapatkan 48 responden yang terbagi menjadi tiga kelompok, yaitu kelompok diskusi, kelompok penyuluhan, dan kelompok kontrol yang masing-masing $\mathrm{n}=16$. Analisis data yang digunakan adalah statistika nonparametrik dengan uji Wilcoxon, Kruskal-Wallis dan Mann Whitney dengan $\alpha=0,05$. Hasil uji statistik menunjukkan bahwa terdapat perubahan pengetahuan pada kelompok yang diintervensi dengan metode diskusi kelompok dan penyuluhan $(\mathrm{p}<0,05)$, namun tidak terdapat perubahan persepsi pada kelompok intervensi $(\mathrm{p}>0,05)$.
\end{abstract}

Kata Kunci: Remaja, Diskusi Kelompok, Penyuluhan, Pengetahuan, Persepsi

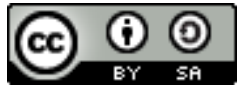

This is an open-acces article distributed under the terms of the Creative Commons Attribution-ShareAlike 4.0 International License.

\section{PENDAHULUAN}

Masa remaja diartikan sebagai masa transisi perkembangan antara masa anak-anak menuju dewasa yang diawali oleh masa pubertas, yaitu masa terjadinya perubahan fisik dan psikologis (Santrock, 2007). Berdasarkan hasil Sensus Penduduk tahun 2015, jumlah penduduk kelompok usia remaja ada sekitar 66 juta (25\%) dari jumlah total penduduk Indonesia. Jumlah yang cukup besar dengan berbagai permasalahan yang sangat kompleks, antara lain seksualitas, nafza, HIV dan AIDS yang membutuhkan pendekatan secara khusus (BKKBN, 2013).

Pertumbuhan dan perkembangan yang pesat ditunjukkan dengan rasa keingintahuan yang besar, keinginan untuk bereksperimen, berpetualangan, dan mencoba bermacam tantangan, selain cenderung berani mengambil risiko tanpa pertimbangan matang terlebih 
dahulu (IDAI, 2013). Dalam rangka mencari pengetahuan tentang seks, ada remaja yang melakukannya secara terbuka bahkan mencoba melakukan eksperimen dalam kehidupan seksual (Kusmiran, 2011).

Pada perkembangan jaman dan kemajuan teknologi menyebabkan adanya pergeseran dan perubahan nilai tentang seksualitas sehingga membuat seks dianggap sesuatu yang tidak sakral lagi. Hal ini terlihat dari perilaku pacaran remaja seperti menyentuh, bergandengan, berpelukan, petting (bercumbu tanpa melakukan coitus), dan bahkan bersenggama dengan lawan jenis (Wijayanto, 2013).

Akibat perilaku seksual remaja yang berisiko menyebabkan peningkatan ancaman HIV/AIDS. Diperkirakan 20-25\% dari infeksi HIV di dunia terjadi pada remaja. Demikian halnya dengan IMS yang tertinggi di remaja, khususnya remaja perempuan pada kelompok usia 15-29 tahun. Disinyalir bahwa saat ini di Indonesia terjadi 2,6 juta aborsi setiap tahunnya. Sebanyak 700.000 diantaranya pelakunya adalah remaja. (IDAI, 2003).

Kurangnya pemahaman tentang perilaku seksual pada remaja sangat merugikan bagi remaja sendiri termasuk keluarganya (Soetjiningtsih, 2004). Remaja perlu mengetahui kesehatan reproduksi agar memiliki informasi yang benar mengenai proses reproduksi. Dengan informasi yang benar, diharapkan remaja memiliki sikap dan tingkah laku yang bertanggung jawab mengenai proses reproduksinya (IDAI, 2013).

Salah satu metode penyampaian pendidikan seksual melalui pendidikan teman sebaya, yaitu dengan diskusi antar teman sebaya dan penyuluhan pendidikan seksual. Dengan metode ini diharapkan mampu mengurangi kecenderungan perilaku seksual remaja yang berisiko.

Berdasarkan studi pendahuluan di SMAN 1 Kandat Kabupaten Kediri, pada Tahun Ajaran 2016-2017 terdapat 6 siswi yang putus sekolah karena hamil pranikah dan kenakalan remaja seperti seks bebas. Pada Tahun Ajaran 2017-2018 tercatat sebanyak 9 siswi yang putus sekolah dikarenakan hamil dan seks bebas, dan pada Tahun Ajaran 2018-2019 terdapat 5 siswi yang putus sekolah karena hamil dan seks bebas.

Tingginya perilaku berisiko pada remaja merupakan hasil akhir dari sifat khas remaja, pengetahuan remaja tentang kesehatan akan mempengaruhi persepsinya terhadap perilaku seksual, nilai moral yang dianut, serta kondisi lingkungan yang turut mempengaruhi. Secara tidak langsung masalah kesehatan remaja tersebut turut menghambat laju pembangunan manusia (human development) di Indonesia, dan pencapaian pembangunan tujuan milenium (millenium development goal) (IDAI, 2013).

Berdasarkan uraian yang telah dijabarkan di atas maka penulis tertarik untuk meneliti "Perbedaan Efektivitas Diskusi Kelompok dan Penyuluhan Pendidikan Seksual terhadap Perubahan Persepsi tentang Perilaku Seksual Siswi SMAN 1 Kandat Kabupaten Kediri”.

\section{METODE}

Penelitian ini merupakan studi eksperimental dengan menggunakan desain penelitan pre-post test with control group design untuk membandingkan efektivitas diskusi kelompok dan penyuluhan pendidikan seksual terhadap perubahan persepsi tentang perilaku seksual siswi SMAN 1 Kandat.

Penelitian dilakukan di SMAN 1 Kandat Kabupaten Kediri pada bulan September 2019 Teknik pengambilan sampel dengan menggunakan purposive sampling. Sampel pada penelitian ini adalah siswi yang berusia 18 tahun dan mengikuti proses diskusi atau penyuluhan pendidikan seksual yang diberikan, yaitu 48 siswi.

Variabel dalam penelitian ini adalah Variabel independent, yaitu diskusi kelompok atau penyuluhan pendidikan seksual. Variabel dependent adalah pengetahuan terkait seksualitas dan persepsi tentang perilaku seksual remaja.

Dalam penelitian ini instrument yang digunakan untuk mengumpulkan data menggunakan kuesioner yang terdiri dari pertanyaan pengukuran pengetahuan terkait 
seksualitas dan persepsi tentang perilaku seksual. Setelah dilakukan penyusunan instrument maka dilakukan uji validitas dan reliabilitas.

Setiap responden diberikan penjelasan mengenai tujuan dan cara penelitian kemudian mengisi informed consent. Responden dibagi menjadi 3 kelompok, kelompok diskusi, penyuluhan dan kontrol. Lalu dilakukan pre-test awal kepada keseluruhan subjek penelitian. Peneliti menjadi fasilitator dalam diskusi kelompok dan menjadi narasumber yang memberikan materi penyuluhan pendidikan seksual. Setelah 7 hari dilakukan post-test kepada keseluruhan subjek penelitian.

\section{HASIL}

\section{Hasil Uji Prasyarat Analisis Normalitas}

Hasil analisis data pada uji normalitas dilakukan dengan menggunakan uji Kolmogorov-Smirnov diperoleh bahwa data instrument pengetahuan terkait seksualitas baik pada pre maupun post-test terdistribusi normal $(\mathrm{p}>0,05)$. Sedangkan pada data instrument persepsi tentang seksualitas baik pada pre maupun post-test terdistribusi tidak normal $(\mathrm{p}<$ $0,05)$. Selanjutnya data sampel dianalisis dengan menggunakan statistika non-parametrik.

\section{Hasil Uji Perbedaan Pengetahuan terkait Seksualitas pada Kelompok Diskusi, Penyuluhan, dan Kontrol}

Tabel 1 Hasil Uji Perbedaan Pengetahuan terkait Seksualitas pada Kelompok Diskusi, Penyuluhan, dan Kontrol (pre dan post-test)

\begin{tabular}{ccc}
\hline Kelompok & Nilai Sig & Keterangan \\
\hline Diskusi & 0,011 & Signifikan \\
Penyuluhan & 0,002 & Signifikan \\
Kontrol & 0,506 & Tidak signifikan \\
\hline
\end{tabular}

Berdasarkan tabel 1 dengan menggunakan Wilcoxon Signed Rank Test menunjukkan ada perbedaan yang bermakna $(\mathrm{p}<0,05)$ terhadap pengetahuan terkait seksualitas pada kelompok diskusi dan penyuluhan. Sedangkan pada kelompok kontrol tidak ada perbedaan bermakna $(p>0,05)$ terhadap pengetahuan terkait seksualitas.

\section{Hasil Uji Perbedaan Persepsi tentang Perilaku Seksual pada Kelompok Diskusi, Penyuluhan, dan Kontrol}

Tabel 2 Hasil Uji Perbedaan Persepsi tentang Perilaku Seksual pada Kelompok Diskusi, Penyuluhan, dan Kontrol (pre dan post-test)

\begin{tabular}{ccc}
\hline Kelompok & Nilai Sig & Keterangan \\
\hline Diskusi & 0,132 & Tidak signifikan \\
Penyuluhan & 0,334 & Tidak signifikan \\
Kontrol & 0,315 & Tidak signifikan \\
\hline
\end{tabular}

Berdasarkan tabel 2 dengan menggunakan Wilcoxon Signed Rank Test menunjukkan tidak ada perbedaan yang bermakna $(\mathrm{p}>0,05)$ terhadap persepsi tentang perilaku seksual pada kelompok diskusi, penyuluhan, maupun kelompok kontrol. 
Analisis Perbedaan Efektivitas antara Diskusi Kelompok dan Penyuluhan Pendidikan Seksual terhadap Perubahan Pengetahuan terkait Seksualitas dan Persepsi tentang Perilaku Seksual (3 kelompok)

Tabel 3 Analisis Hasil Pre dan Post-test Kelompok Diskusi, Kelompok Penyuluhan dan Kelompok Kontrol terhadap Perubahan Pengetahuan terkait Seksualitas

\begin{tabular}{cccccc} 
& \multicolumn{3}{c}{ Nilai Mean Rank } & \multirow{2}{*}{ Nilai Sig } & \multirow{2}{*}{ Keterangan } \\
\cline { 2 - 4 } Pre-test & Diskusi & Penyuluhan & Kontrol & & \\
Post-test & 23,16 & 24,06 & 26,28 & 0,800 & Tidak signifikan \\
\hline
\end{tabular}

Berdasarkan hasil analisis data dengan menggunakan uji Kruskal-Wallis terdapat perubahan antara hasil pre dan post-test pengetahuan pada kelompok penyuluhan dan kelompok diskusi. Hasil post-test kedua kelompok intervensi terjadi peningkatan, sedangkan hasil post-test pada kelompok kontrol terjadi penurunan tingkat pengetahuan terkait seksualitas. Hal ini dibuktikan dari hasil nilai mean rank pada masing-masing kelompok. Saat pre-test belum ada perbedaan yang bermakna terhadap perubahan pengetahuan terkait seksualitas karena nilai $p$-value $>0,05$, kemudian setelah post-test terdapat perbedaan yang bermakna terhadap peruahan pengetahuan terkait seksualitas karena nilai $p$-value $<0,05$. Maka dapat disimpulkan bahwa intervensi berupa diskusi kelompok dan penyuluhan pendidikan seksual mampu merubah tingkat pengetahuan terkait seksualitas.

Tabel 4 Analisis Hasil Pre dan Post-test Kelompok Diskusi, Kelompok Penyuluhan dan Kelompok Kontrol terhadap Perubahan Persepsi tentang Perilaku Seksual

\begin{tabular}{cccccc} 
& \multicolumn{3}{c}{ Nilai Mean Rank } & \multirow{2}{*}{ Nilai Sig } & \multirow{2}{*}{ Keterangan } \\
\cline { 2 - 3 } Pre-test & Diskusi & Penyuluhan & Kontrol & & \\
Post-test & 27,06 & 25,06 & 21,38 & 0,479 & Tidak signifikan \\
\hline
\end{tabular}

Hasil pre dan post-test persepsi tentang perilaku seksual pada 3 kelompok, yaitu pada kelompok diskusi, kelompok penyuluhan, dan kelompok kontrol. Terlihat bahwa secara numerik terdapat perubahan antara hasil pre dan post-test persepsi pada kelompok penyuluhan dan kelompok diskusi. Hasil post-test kedua kelompok intervensi terjadi peningkatan, sedangkan hasil post-test pada kelompok kontrol terjadi penurunan. Hasil pretest tidak ada perbedaan yang bermakna terhadap perubahan persepsi tentang perilaku seksual karena nilai $p$-value $>0,05$, lalu setelah post-test nilai $p$-value $>0,05$ yang berarti bahwa tidak ada perbedaan yang bermakna terhadap perubahan persepsi tentang perilaku seksual. Maka dapat disimpulkan bahwa persepsi responden tentang perilaku seksual sebelum dan sesudah intervensi adalah sama.

\section{Analisis Perbedaan Efektivitas antara Diskusi Kelompok dan Penyuluhan Pendidikan Seksual terhadap Perubahan Pengetahuan terkait Seksualitas dan Persepsi tentang Perilaku Seksual (2 kelompok)}

Hasil uji perbedaan efektivitas diskusi kelompok dan penyuluhan pendidikan seksual terhadap perubahan pengetahuan terkait seksualitas dan persepsi tentang perilaku seksual dilakukan dengan membandingkan hasil pre dan post-test antara kelompok kelompok diskusi dan kelompok penyuluhan, kelompok diskusi dan kelompok kontrol, serta kelompok penyuluhan dan kelompok kontrol dengan menggunakan uji Mann-Whitney. 
Tabel 5 Analisis Hasil Uji Beda terhadap Pengetahuan terkait Seksualitas

\begin{tabular}{clccc}
\hline \multicolumn{2}{c}{ Instrument Pengetahuan } & Nilai Z & Nilai Sig & Keterangan \\
\hline \multirow{3}{*}{ Pre-test } & Diskusi-Penyuluhan & $-0,194$ & 0,864 & Tidak signifikan \\
& Diskusi-Kontrol & $-0,643$ & 0,520 & Tidak signifikan \\
& Penyuluhan-Kontrol & $-0,466$ & 0,641 & Tidak signifikan \\
& Diskusi-Penyuluhan & $-1,992$ & 0,046 & Signifikan \\
\multirow{3}{*}{ Post-test } & Diskusi-Kontrol & $-2,947$ & 0,003 & Signifikan \\
& Penyuluhan-Kontrol & $-3,625$ & 0,000 & Signifikan \\
\hline
\end{tabular}

Hasil uji beda pre-test dengan membandingkan antara kelompok kelompok diskusi dan kelompok penyuluhan, kelompok diskusi dan kelompok kontrol, serta kelompok penyuluhan dan kelompok kontrol didapatkan hasil nilai $\mathrm{Z}$ hitung $<-1,96$ dan nilai $p$-value $>$ 0,05, sehingga dapat disimpulkan bahwa tidak ada perbedaan yang bermakna terhadap pengetahuan terkait seksualitas pada saat pre-test. Sedangkan hasil uji beda saat post-test adalah nilai $\mathrm{Z}$ hitung $>-1,96$ dan nilai $p$-value $<0,05$, sehingga dapat disimpulkan bahwa ada perbedaan yang bermakna terhadap pengetahuan terkait seksualitas saat post-test.

Tabel 6 Analisis Hasil Uji Beda terhadap Persepsi tentang Perilaku Seksual

\begin{tabular}{clccl}
\hline \multicolumn{2}{c}{ Instrument Persepsi } & Nilai Z & Nilai Sig & Keterangan \\
\hline \multirow{3}{*}{ Pre-test } & Diskusi-Penyuluhan & $-0,433$ & 0,665 & Tidak signifikan \\
& Diskusi-Kontrol & $-1,173$ & 0,241 & Tidak signifikan \\
& Penyuluhan-Kontrol & $-0,789$ & 0,430 & Tidak signifikan \\
& Diskusi-Penyuluhan & $-1,202$ & 0,229 & Tidak signifikan \\
\multirow{3}{*}{ Post-test } & Diskusi-Kontrol & $-1,872$ & 0,061 & Tidak signifikan \\
& Penyuluhan-Kontrol & $-0,751$ & 0,453 & Tidak signifikan \\
\hline
\end{tabular}

Hasil uji beda pre dan post-test dengan membandingkan antara kelompok kelompok diskusi dan kelompok penyuluhan, kelompok diskusi dan kelompok kontrol, serta kelompok penyuluhan dan kelompok kontrol didapatkan hasil nilai $\mathrm{Z}$ hitung $<-1,96$ dan nilai $p$-value $>$ 0,05, sehingga dapat disimpulkan bahwa tidak ada perbedaan yang bermakna terhadap persepsi tentang perilaku seksual pada saat pre dan post-test. Jadi, intervensi yang diberikan belum mampu merubah persepsi tentang perilaku seksual. Terbukti dari hasil uji statistik yang tidak menunjukkan adanya perubahan yang signifikan pada hasil post-test.

Dengan demikian hipotesis penelitian tidak terbukti karena tidak terdapat perbedaan efektifitas antara diskusi kelompok dan penyuluhan pendidikan seksual terhadap perubahan persepsi tentang perilaku seksual siswi SMAN 1 Kandat.

\section{PEMBAHASAN}

\section{Gambaran Perubahan Pengetahuan terkait Seksualitas pada Kelompok Intervensi}

\section{A. Kelompok Diskusi}

Berdasarkan hasil uji statistik membuktikan bahwa intervensi berupa diskusi kelompok memberikan perubahan yang signifikan terhadap pengetahuan terkait seksualitas. Metode diskusi dua arah antara fasilitator dan peserta diskusi menjadikan informasi yang disampaikan menjadi lebih mudah diterima, terlebih informasi yang diberikan disampaikan oleh kelompok sebaya (peer group). Peran teman sebaya bagi remaja sangat berarti dalam memperoleh informasi yang akan mempengaruhi sikap dan perilaku remaja terhadap isu seksualitas.

Hal ini sejalan dengan penelitian yang dilakukan oleh Hayatun Nisma (2008) bahwa pengetahuan kesehatan reproduksi yang dinilai dari penyampaian pendidikan 
kesehatan reproduksi oleh kelompok sebaya (peer group) dengan hasil uji statistik yang signifikan. Artinya, pendidikan kesehatan yang disampaikan oleh kelompok sebaya (peer group) berpengaruh terhadap pengetahuan kesehatan reproduksi remaja di SMP Negeri 2 Kasihan Bantul Yogyakarta.

\section{B. Kelompok Penyuluhan}

Penyuluhan pendidikan seksual memberikan perubahan yang signifikan terhadap pengetahuan terkait seksualitas. Peserta penyuluhan merasa lebih nyaman dan lebih terbuka bila yang menyampaikan materi tersebut adalah mahasiswa. Media yang digunakan untuk menyampaikan materi juga berpengaruh, maka peneliti menyiapkan media presentasi yang tidak seperti biasanya dan memutarkan video-video yang menarik namun didalamnya terdapat informasi yang penting.

Hasil penelitian lain yang mendukung adalah penelitian yang dilakukan oleh Ardin Prima Massolo, dkk. (2011) bahwa ada perbedaan dan perubahan rata-rata skor pengetahuan baik sebelum dan sesudah penyuluhan pada kelompok eksperimen. Sehingga dapat disimpulkan bahwa ada pengaruh penyuluhan kesehatan reproduksi terhadap pengetahuan siswa SMAN 1 Masohi tentang seksual pranikah.

Notoatmodjo (2007) berpendapat bahwa pengetahuan merupakan hasil tidak tahu menjadi tahu, ini terjadi setelah seseorang melakukan pengindraan terhadap suatu objek tertentu dan adanya stimulus, dikatakan juga bahwa untuk merubah pengetahuan, sikap dan perilaku

Menurut Bobak (2006), umur mempengaruhi pengetahuan, dimana umur 17-18 tahun merupakan remaja akhir dimana mulai memahami dirinya dan lebih mudah menerima informasi sehingga mempengaruhi pengetahuan mereka terutama tentang seksualitas.

\section{Gambaran Perubahan Persepsi tentang Perilaku Seksual pada Kelompok Intervensi A. Kelompok Diskusi}

Meskipun hasil post-test menunjukkan sebagian besar responden memiliki persepsi positif tentang perilaku seksual yang artinya responden tidak setuju terhadap perilaku seksual pranikah, namun hasil statistik belum menunjukkan adanya perubahan yang bermakna pada perubahan persepsi tentang seksualitas responden setelah diskusi kelompok.

Dalam diskusi kelompok terdapat hubungan antara pengetahuan dan praktek sehari-hari. Namun kelemahan dari metode diskusi ini terdapat responden yang dominan berbicara atau terdapat responden yang pasif. Untuk menghindari hal ini fasilitator (peneliti) harus dapat mengontrol situasi sehingga semua peserta diskusi dapat menyampaikan pendapatnya.

Proses timbulnya persepsi antara lain dipengaruhi oleh tingkat pengetahuan tentang seksualitas dan pengalaman responden yang dalam hal ini terkait dengan perilaku seksual. Pengetahuan dan pengalaman responden akan disimpan dalam memorinya dan akan digunakan sebagai referensi untuk menghadapi stimuli baru. Terlebih lagi peran teman sebaya menimbulkan adanya perasaan memiliki (sense of commitment) sehingga peserta diskusi tidak merasa canggung dan lebih bebas mengekspresikan pendapatnya. Dengan demikian, pengetahuan yang baru memungkinkan dapat merubah persepsi responden tentang seksualitas.

Metode diskusi yang dilakukan merupakan proses dasar dalam memberikan pemahaman pengetahuan tentang informasi kesehatan reproduksi bagi remaja dalam memberi gambaran terhadap persepsi remaja pada situasi dan kondisi yang menyangkut kesehatan reproduksinya sehingga memberi pertimbangan psikologis terhadap permasalahan kesehatan reproduksi yang menyangkut dengan sebab akibatnya. Dengan 
pertimbangan tersebut, maka remaja tidak hanya merasa wajib, akan tetapi juga meningkat pada kesadaran akan kebutuhan untuk berprilaku sehat secara reproduksi (Sri Handayani $d k k ., 2009)$.

\section{B. Kelompok Penyuluhan}

Hasil post-test belum menunjukkan adanya perubahan yang bermakna pada perubahan persepsi tentang seksualitas responden penyuluhan pendidikan seksual. penyuluhan pendidikan seksual yang diberikan sudah sesuai dengan sasaran penyuluhan.

Pemberian informasi kesehatan reproduksi dengan metode penyuluhan cukup efektif untuk meminimalkan risiko pembahasan diluar topik yang dikehendaki. Yang menjadi kelemahan metode penyuluhan adalah interaksi yang bersifat terpusat kepada narasumber sehingga narasumber kurang dapat mengetahui secara pasti sejauh mana responden menguasai materi penyuluhan. Selain itu, responden seolah-olah diarahkan untuk mengikuti pemikiran narasumber sehingga responden kurang dapat mengembangkan kecakapannya dalam berpendapat.

\section{Gambaran Perubahan Pengetahuan terkait Seksualitas dan Persepsi tentang Perilaku Seksual pada Kelompok yang Tidak Diintervensi (Kelompok Kontrol)}

Hasil uji statistik tidak terdapat perubahan pengetahuan dan persepsi pada kelompok kontrol. Dengan kata lain, tingkat pengetahuan dan persepsi saat pre-test maupun post-test adalah sama.

Tidak adanya perbedaan yang signifikan terhadap pengetahuan dan persepsi pada kelompok kontrol dikarenakan pada kelompok kontrol tidak mendapat informasi tentang pendidikan kesehatan reproduksi, sehingga tidak mempengaruhi pengetahuan maupun persepsi pada kelompok kontrol tentang perilaku seksual.

Maka upaya untuk mempengaruhi atau mengajak individu ataupun kelompok tidak terjadi pada kelompok kontrol ini. Sehingga pengetahuan pada kelompok ini akan rendah dan pengetahunanya bersifat tidak langgeng dan persepsinya tidak berubah karena tidak mendapatkan pendidikan kesehatan ataupun informasi yang dapat mempengaruhi mereka.

Hal ini sesuai dengan pendapat Suliha, dkk (2001) bahwa pendidikan kesehatan merupakan upaya untuk memberikan informasi untuk meningkatkan kemampuan baik pengetahuan, sikap dan perilaku individu, kelompok dan masyarakat.

Kondisi tidak adanya perubahan yang bermakna pada kelompok kontrol dijelaskan pula oleh Yeni Nur Ikwal Musaini, $d k k$. (2011), bahwa pada kelompok kontrol diperoleh hasil tidak mempunyai nilai yang bermakna antara pre-test dan post-test. Hal ini dimungkinkan adanya faktor dari dalam diri siswa, yaitu terjadi penolakan terhadap pernyataan yang dihadapi dalam tes karena siswa perokok aktif sehingga terjadi kontradiksi antara pernyataan dan fenomena.

\section{Gambaran Perbedaan Efektivitas antara Diskusi Kelompok dan Penyuluhan Pendidikan Seksual terhadap Perubahan Persepsi tentang Perilaku Seksual}

Hasil post-test menunjukkan perbedaan yang bermakna terhadap peruahan pengetahuan terkait seksualitas dengan nilai $p$-value $0,000(\mathrm{p}<0,05)$. Maka dapat disimpulkan bahwa intervensi berupa diskusi kelompok dan penyuluhan pendidikan seksual mampu merubah tingkat pengetahuan terkait seksualitas. Namun, tidak ada perbedaan yang bermakna terhadap perubahan persepsi tentang perilaku seksual. Dengan kata lain bahwa persepsi responden tentang perilaku seksual sebelum dan sesudah intervensi adalah sama.

Kurang efektifnya pendidikan seksual dalam penelitian ini untuk merubah persepsi tentang perilaku seksual pada responden lebih dikarenakan faktor-faktor lain yang terdapat pada penelitian ini, diantaranya pengalaman pribadi responden, salah satunya adalah sebagian 
responden sudah pernah mendapatkan pendidikan seks sebelumnya dan pengaruh orang lain yang dianggap penting, misalnya status pacaran yang dapat mempengaruhi.

Dalam proses pendidikan banyak faktor yang harus diperhatikan agar proses pendidikan dapat berjalan dengan baik. Aspek metode pendidikan bukanlah satu-satunya aspek yang mempengaruhi, tetapi juga masih dipengaruhi oleh faktor bahan atau materi yang diajarkan, faktor pendidik atau fasilitator, suasana, kondisi peserta, media pembelajaran serta kepentingan (Sri Handayani, dkk. 2009).

\section{KESIMPULAN}

Terdapat perbedaan pengetahuan terkait seksualitas yang bermakna pada kelompok yang diintervensi berupa pendidikan seksual dengan metode diskusi kelompok dan penyuluhan yang terbukti dengan nilai hasil analisis $\mathrm{p}<0,05$.

Tidak terdapat perbedaan persepsi tentang perilaku seksual yang bermakna pada kelompok yang diintervensi berupa pendidikan seksual dengan metode diskusi kelompok dan penyuluhan yang terbukti dengan nilai hasil analisis $\mathrm{p}>0,05$.

Tidak terbukti adanya perbedaan efektivitas antara diskusi kelompok dan penyuluhan pendidikan seksual terhadap perubahan persepsi tentang perilaku seksual siswi SMAN 1 Kandat.

\section{SARAN}

Pengetahuan yang telah didapatkan harapannya dapat mencadi acuan yang berguna bagi remaja dalam menyikapi masalah kesehatan reproduksi. Diharapkan kepada peneliti selanjutnya untuk menambah instrument pengalaman perilaku seksual pada subjek penelitian.

\section{REFERENSI}

Arikunto. 2006. Prosedur Penelitian Suatu Pendekatan Praktik. Jakarta: Rineka Cipta.

Bobak. 2006. Keperawatan Maternitas. Jakarta: Penerbit Buku Kedokteran EGC.

Direktorat Bina Ketahanan Remaja. 2013. Kurikulum Diklat Teknis Pengelolaan PIK Remaja/Mahasiswa Bagi Pengelola, Pendidik Sebaya Dan Konselor Sebaya PIK Remaja/Mahasiswa. Jakarta: BKKBN.

Handayani, Sri. Efektivitas Metode Diskusi Kelompok Dengan dan Tanpa Fasilitator pada Peningkatan Pengetahuan, Sikap dan Motivasi Remaja tentang Perilaku Seks Pranikah. Berita Kedokteran Masyarakat, Vol. 25, No. 3, September 2009.

IDAI, 2013. Kesehatan Reproduksi Remaja dalam Aspek Sosial, (Online), (http://www.idai.or.id/public-articles/seputar-kesehatan-anak/kesehatan-reproduksiremaja-dalam-aspek-sosial.html, diakses 18 Agustus 2019).

Khisbiyah, Yayah; Desti Murdiana; Wijayanto. 1995. Konsekuensi psikologis dan sosioekonomi yang menyertai kehamilan tak dikehendaki di kalangan remaja. Yogyakarta: Pusat Pengkajian Strategi dan Kebijakan.

Kusmiran, E. 2011. Kesehatan Reproduksi Remaja dan Wanita. Jakarta: Salemba Medika.

Massolo, Ardin Prima, dkk. 2011. Pengaruh Penyuluhan Kesehatan Reproduksi terhadap Pengetahuan dan Sikap Remaja tentang Seksual Pranikah di SMAN 1 Masohi Tahun 
2011. Tugas Akhir. Tidak diterbitkan, Fakultas Kesehatan Masyarakat Universitas Hasanuddin, Makassar.

Musaini, Yeni Nur Ikwal, Burhannudin Ichsan, dan Sri Wahyu Basuki. Pengaruh Pendidikan Kesehatan terhadap Pengetahuan dan Sikap Merokok pada Siswa Laki-Laki Kelas XI SMK Murni 1 Surakarta. Jurnal Kesehatan, ISSN 1979-7621, Vol. 4, No. 2, Desember 2011: 164-176.

Nisma, Hayatun. 2008. Pengaruh Penyampaian Pendidikan Kesehatan Reproduksi Oleh Kelompok Sebaya (Peer Group) Terhadap Pengetahuan Kesehatan Reproduksi Remaja Di Smp Negeri 2 Kasihan Bantul Yogyakarta. Tugas Akhir. Tidak diterbitkan, Fakultas Kedokteran Universitas Muhammadiyah Yogyakarta, Yogyakarta.

Notoatmodjo. 2007. Kesehatan Masyarakat Ilmu dan Seni. Jakarta: Rineka Cipta.

Santrock, J. W. 2007. Remaja. Edisi Kesebelas. Jakarta: Erlangga.

Soetjiningsih. 2004. Tumbuh Kembang Remaja dan Permasalahanya. Jakarta: CV. Sagung Seto 